\title{
THE TAX SYSTEM AND TAXPAYERS BEHAVIOR
}

\author{
Brindusa Tudose \\ Affiliation Petre Andrei University of Iasi \\ brindusatudose@gmail.com \\ Gabriela Tiplic \\ Administrative Economic College - no. 1, Iași \\ gabriela_tiplic@yahoo.com
}

\begin{abstract}
The aim of the paper was to examine the behavioural coordinates of tax subjects and the intensity of the interaction between taxpayers and authorities. Research on the behaviour of subjects of the tax system is justified given the tension existing between taxpayers, on the one hand, and the tax system, on the other. The tax systems of the world have been classified into two models: antagonistic and synergistic. As long as in Romania the tax elements have been and continue to be an overwhelming burden on taxpayers, their behaviour has evolved and adjusted to a negative outlook. This type of behaviour, associated with the behaviour of tax authorities built on lack of trust and virulent anti-tax avoidance strategies, has generated a tense and antagonistic tax environment.
\end{abstract}

\section{Keywords}

tax system; tax subjects; tax behaviour; antagonism; synergy

\section{JEL Classification}

H30

\section{Introduction}

In order to understand and assess the behaviour of tax subjects, it is essential to have thorough knowledge of the particular aspects entailed by the tax system. To sum up the developments in the literature in the field, two approaches stand out:

a) the limitative approach, according to which the tax system is interpreted either in terms of the body of law regulating taxation elements (Condor, 1994) or in terms of the sum of taxes and duties collected from taxpayers (Hoanţă, 1997); this approach lays emphasis only on an intermediate objective of the tax system (regulation, i.e. the collection of tax obligations and the provision of financial resources to the public budget);

b) the extensive approach, according to which the tax system involves a set of requirements and principles regarding the level, apportionment and collection of taxes and the socio-economic objectives of tax policy; this novel view argues that the tax system incorporates not only the taxation concepts, principles, methods and procedures but also the institutional setup intended to mobilise, apportion, collect and allocate the collected budget revenues (Corduneanu, 1998; Moraru et al., 2007; Boglea, 2010).

Based on these two approaches, we subscribe to the idea that the tax system is more than a mere compendium of arid tax laws and economic data; it represents the expression of intra-community relations between individuals, between taxpayers and their governments (Cordes et al., 2005). 
The structuralist approach predetermines us to admit that a tax system is comprised of three elements: a) taxation; b) the tax authority and taxpayers (including their behaviour); and c) the interactions between the subjects in the system.

\section{Taxation - a factor exerting a major impact on tax subjects' behaviours}

In the area of legal approaches (Şaguna, 2003; Tulai, 2003; Florescu et al., 2005), taxation is viewed as the sum of legislative regulations on tax obligations. Moving beyond the scope of economic approaches, taxation covers a larger area, incorporating not only regulations on tax obligations, but also the principles, rules and practices of the establishment and collection of taxes (Zaharia, 2002; Văcărel, 2006). Given that two large groups of actors interact in the tax sphere, the behavioural approach defines taxation in terms of the relations between government authorities, on the one hand, and tax payers, whether private individuals or legal persons, on the other, recognising that the notions of taxation and tax are two faces of the same coin (Țâtu et al. 2004).

Although it has been defined and interpreted as having several meanings, we shall retain only the common core of all the debates: taxation cannot be separated from taxes (as a generic term) ${ }^{1}$. Consequently, in order to properly grasp taxation one needs to understand the tax elements that compose it.

Elements of taxation are the obligatory payments (transfers) that taxpayers must make in the amount, within the deadline and in compliance with the conditions laid down in the legislation in force. To avert any negative effects, taxation must be designed in such a way as to meet the following requirements: ensure economic efficiency and social equity; contribute to the mitigation of macroeconomic imbalances; simplify operations for the collection of tax, contribution and duties; and create the necessary framework to prevent fraud and tax evasion (Tudose, 2008).

The elements of taxation reflect a variety of practices. From the perspective we are interested in, the most relevant criterion is the substance and the form (the apportionment and collection) based on which elements of taxation are classified as direct and indirect.

The elements of direct taxation are established nominally, private individuals and/or legal persons being liable for tax depending on their income or wealth, taking into account their capacity to pay and the size of the taxable base. Such elements of direct taxation are nominative (taxpayers are identified clearly and unambiguously), have a definite amount and a clearly determined payment deadline ${ }^{2}$. This category includes: a) real, objective or product taxes, determined by assets owned by the taxpayer (land, buildings, and vehicles); b) personal or subjective taxes, levied on income or wealth, linked to the personal situation of the tax subject.

The elements of indirect taxation reflect the amounts that are due to the budget on the sale of goods or provision of services, being included in the selling prices and their respective rates; they are paid into the public budget by producers, traders or service providers and are incurred by the final consumers of taxable goods and services. Compared to direct taxes, indirect taxes have the following features: the tax burden is regressive (as it takes a larger share of the income of low-income taxpayers); they are inequitable (they are not set in line with the capacity to pay $^{3}$ ); they deliver high tax revenues (as they depend on sales volumes); and they are voluntary to a certain extent

\footnotetext{
${ }^{1}$ We used the notion of tax as a generic term, yet we must note that not all elements of taxation take the form of tax (there can also be duties and contributions).

${ }^{2}$ The direct proportionality between the amount of tax and the size of the taxable base must be understood as follows: less tax is paid on a smaller taxable base, while more tax is paid on a larger taxable base. For example, vehicle tax is lower for means of transport with a low cylinder capacity and higher for means of transport with greater cylinder capacity.

${ }^{3}$ For instance, a beggar or a millionaire pay equal value-added tax when buying a loaf of bread.
} 
(those who incur them pay tax in so far as they purchase goods and services whose price includes indirect tax elements). Unlike the elements of direct taxation (levied on income or wealth), elements of indirect taxation are targeted on how income and wealth are spent. This category includes: a) general consumption taxes, applicable to all categories of goods and services (VAT) and special duties applied only to certain categories of goods (excise, custom duties) and services (administrative, consular, legal, etc.).

\section{Tax subjects and their behaviour}

Over time, taxation elements have prompted discussions and disputes, especially due to the contradictory interests of the government and taxpayers. For example, direct taxation elements are preferred by the government because they are fair (taking into account the personal situation of the individual) and deliver high tax revenues, while tax rate adjustments do not result in changes in the size of the taxable base. The drawbacks of such taxes stem from the slow rate of collection, the complexity of taxation and higher likelihood of fraud. Taxpayers do not appreciate this type of tax obligations as they incur them straightforwardly and discourage them from making additional revenue (Inceu et al., 2008). As for the elements of indirect taxation, the government prefers to enact them thanks to the fast collection rate, low collection costs, reduced opportunities for fraud and higher tax yield. On the contrary, taxpayers view them as unfair (as they apply to consumption) and blame them for the "burden" placed on the "shoulders" of the impoverished population, whose income is (almost) exclusively allocated for consumption (Bistriceanu et. al., 2001). The compromise solution was to enact lower tax rates on basic necessities (as in the case of VAT on food and bread, respectively, in Romania).

Despite being unpopular and snubbed by taxpayers of modest financial means, indirect taxation elements continue to contribute a larger share in the accumulation of tax revenue in developing nations. In contrast, in developed countries, elements of direct taxation contribute to a greater extent to the accumulation of tax resources. This is because in developing countries, due to poor economic performance, income and wealth are comparatively lower than in developed countries (consequently, the amount of resources drawn from elements of direct taxation is lower) (Văcărel, 2006); moreover, tracking those making profits or income is more difficult and costly, while elements of indirect taxation (VAT, excise, customs duties) are easy to quantify, cheap to collect and inexpensive to cash in; this is because the latter are included in the selling price of products or services, and any discontent triggered by a potential increase is not directed at the government (as in the case of elements of direct taxation) but at business operators.

Taxpayers (also called tax subjects) are natural or legal persons liable to pay a share of their revenue or property to the public budget. For each individual taxation element the legal framework lists the taxpayer categories.

The tax authority is represented by those specialised entities that set in motion the taxation mechanism in order to secure the ultimate goal. Its role is to implement tax policy and adjust it to the national and international economic context. Being tasked with collecting tax obligations as effectively as possible, the tax authority aims to identify those taxpayers who evade payment of tax obligations and to enforce statutory penalties.

The structure and operation of the tax system bears the mark of the tax policy enacted by a state, during a given period of time. By incorporating the principles, mechanisms and procedures of taxation and of funding budget expenditures, tax policy shapes the tax system in structural terms (Corduneanu, 1998). 
Research on the behaviour of subjects of the tax system is justified given the tension existing between taxpayers, on the one hand, and the tax system, on the other. The existing literature indicates that although evidence has been provided to support the need to study human psychology as a means to explain economic reality, in practice it has not received the attention it deserves (the proof being the crises that mankind has faced). Specifically, in our case, we are interested in the influence of psychology on the tax decisions of taxpayers; this is because the interaction shapes specific behaviours.

Taxpayers' tax behaviour has been defined as the manner in which they, under the influence of endogenous and exogenous factors, choose to act in relation to tax obligations, to react to tax policy and to interact with other taxpayers and the tax authorities (Bătrâncea, 2013). The attitude towards tax obligations may be positive (generating tax compliance behaviour, based on respecting the letter and the spirit of the law) or negative (triggering non-compliant tax behaviour).

Along the same line, it has been acknowledged that there are two types of behaviour for the compliance case (Kirchler et al., 2008): a) voluntary compliance, which is achieved when the payment of tax obligations was made on the basis of certain moral motivations, to fulfil certain civic duties and b) forced compliance, which is manifested if payment of tax obligations is made out of a desire to avert any negative consequences stemming from failure to pay. Studies (Muehlbacher et al., 2011; Wahl et al., 2010) have shown that the trigger of voluntary compliance is trust in authorities, whereas the trigger of forced compliance is the perception that the authorities use their power to exercise controls, to detect fraudsters and to punish them.

Relatively recent studies (Franzoni, 2000) reveal that achieving the phase of tax compliance is premised on meeting four conditions cumulatively: a) reporting all income; b) accurate determination of tax liabilities; c) the timely filing of tax returns; d) payment within the deadline laid down in the applicable legislation. Failure to meet any of these conditions generates non-compliant behaviour which predetermines evasion. According to this approach, tax evasion emerges as the method by which taxpayers respond to tax pressure when it exceeds a certain threshold deemed acceptable for starting, maintaining and developing a business or in relation to their wealth or current income (Dinga, 2009).

Similar to tax compliance, non-compliance takes two forms: a) lawful noncompliance, resulting in lawful tax avoidance (exploiting loopholes in the tax legislation in order to reduce the tax obligations payable to the public budgets) and $b$ ) unlawful non-compliance, leading to tax fraud, i.e. the intentional violation of legislation through failure to act (such as failure to report all revenues) or through deliberate actions (applying for reimbursement of VAT on the basis of fictitious invoices) (James and Alley, 2002).

Analyses of tax behaviour also devote particular attention to the connection between trust and tax fraud. Studies have shown that low trust in authorities is correlated with high levels of tax fraud (Richardson, 2008).

The analysis of behaviour should also focus necessarily the opposite side: the conduct of tax authorities. This is outlined as the tax authority prioritises its goals: to create a cooperative environment where all taxpayers meet their tax obligations (by facilitating the payment of tax obligations for taxpayers and reducing the potential options for evading payment of obligations) or to collect taxes and duties with maximum efficiency (Bătrâncea, 2013). Although shown as separate options, the two objectives are mutually presupposed.

Due to the diverse cultural, economic and political profiles (which individualise each particular state) there is no set of standard rules on the behaviour of the authorities. Instead, it has been universally acknowledged that there is a set of principles that 
authorities should respect and from which they should not deviate. Collectively named the principles of taxation, they were laid down very early (Smith, 1965) and have been constantly revised in order to eliminate arbitrariness in the field of taxation. Currently, four categories of principles are being discussed (Văcărel, 2006): tax equity principles; financial policy principles; economic policy principles; and socialpolitical principles. Unfortunately, these principles are interpreted from the standpoint of those who hold political power and are applied in accordance with the respective doctrines (social -democratic, liberal, etc.).

\section{Interactions between the tax system subjects}

The intensity of the interaction between taxpayers and authorities oscillates between two poles: from rejection/challenge to support/communication/collaboration. Depending on the position between the two poles, the tax systems of the world have been classified into two models: antagonistic (marked by the mutual distrust of taxpayers vs. tax authority) and synergistic (based on mutual respect and trust).

The tax system that dominates an antagonistic environment is characterised by the lack of mutual trust between taxpayers and the tax authority. The latter suspects taxpayers of tax evasion, treating them as potential evaders. In turn, taxpayers view the tax authority as a sort of "policeman" constantly on the lookout for "criminals". In such a climate, taxpayers become uncooperative and reluctant, being concerned that the tax authority uses its power coercively. This complex of factors and behaviours facilitates inevitably the slide from the lawful to the unlawful sphere of activities (i.e. tax fraud). Studies have revealed that amid persecution and coercion and lack of support/collaboration a "paradigm of constraint” arises (Alm and Torgler, 2011), with many taxpayers being tempted to become tax frauds.

The tax system where a synergistic environment dominates is one where mutual respect and trust prevail. The tax authority makes itself available to the taxpayers, viewing them as its "customers", and shows its willingness to provide tax advisory services. Taxpayers see a partner in the tax authority that advises them in order to avoid tax law violations; as such, they have a positive view of the control and sanction activity (viewing at as justified). In such a climate, taxpayer compliance is achieved largely on a voluntary basis.

\section{Particular aspects of the Romanian tax system}

The starting point for identifying the particular features of Romanian tax system is the analysis of the structure of taxation elements. The analyses conducted (Tudose, 2008) show that the tax systems enacted have undergone changes in the structure of the instituted taxes and duties. In this respect, the elements of direct taxation have had an ever lower share in the formation government budget revenues, whereas the share of elements of indirect taxation has expanded. The situation is justified by the fact that the massive increase in public spending could not be matched by increased resources drawn from direct taxes (due to the decline in the volume of the taxable base and the taxpayers' power). Under these circumstances, it can be seen clearly that tax equity (often discussed by politicians in each of the five governments, even included as an objective on their platforms) has deteriorated in the period after December 1989.

As long as the tax elements have been and continue to be an overwhelming burden on taxpayers, their behaviour has evolved and adjusted to a negative outlook. This type of behaviour, associated with the behaviour of tax authorities built on lack of trust and virulent anti-tax avoidance strategies, has generated a tense and antagonistic tax environment. 
A Deloitte report published in March 2012 on the degree of certainty of tax systems placed the Romanian climate in the "police-criminal" pattern, ranking Romania in the "club" of the least certain states in the EMEA region (Europe, Middle East, Africa). The causes that generated this situation include: the frequency of legislative changes and the deficient relationship between taxpayers and authorities, caused by the lack of transparency, low availability and inadequate training of staff.

That is why, in order to improve the interaction between tax subjects in Romania, steps should be taken to ensure: the simplification of the legislative framework and consistency in tax administration procedures, the reduction in the number of tax obligations, and a review of the attitude of tax authorities (which must become more cooperative, transparent and respond more promptly to taxpayers' requests).

\section{Conclusions}

This paper presents the coordinates that enable the analysis of the behaviours of tax subjects. The main conclusions drawn from the body of the paper are: a) taxpayers' behaviour is determined by specific factors such as the level and structure of taxation, the degree of openness, communication and transparency of the tax authority, the level of culture and education, etc.; b) the behaviour of the authority tax is dependent on the cultural, economic and political profiles of each state; c) the interactions between tax subjects can be framed in according to two models: antagonistic and synergistic; d) the tax climate in Romania is tense, marked by the mutual distrust of tax subjects and falls into the antagonistic pattern.

In light of the above, we consider that the study delivers a double utility: a) scientific, as it presents the state of knowledge in the field and b) practical, as it can serve as a reference for mitigating tensions generated by the conduct of taxpayers, on the one hand, and the tax authority, on the other. The study represents a starting point in developing more extensive future explorations seeking to identify and quantify the impact of the determinants of the behaviour of tax subjects in Romania.

\section{References}

Alm, J., Torgler, B. (2011), Do Ethics Matter? Tax Compliance and Morality, Journal of Business and Ethics, 101 (4), pp. 635-651.

Bistriceanu, Gh., Adochiţei, M. N., Negrea (2001), Finanţele agenţilor economici, Bucureşti, Editura Economică.

Bătrâncea, L. M. (2013), Studii post-doctorale în economie, vol. III, Studii şi cercetări fiscal-bugetare, Bucureşti, Editura Academiei Române.

Boglea, A. V. (2010), Evoluţii ale sistemului fiscal românesc în procesul aderării şi integrării Europene, Cluj-Napoca, Editura Casa Cărţii de Ştiinţă.

Condor, I. (1994), Drept financiar, Bucureşti, Editura Regia Autonomă Monitorul Oficial.

Cordes, J. J., Ebel, R. D., Gravelle, J. G. (2005), The Encyclopedia of Taxation and Tax Policy, 2nd ed., Washington, The Urban Institute Press.

Corduneanu, C. (1998), Sistemul fiscal în ştiinţa finanţelor, Bucureşti, Editura Codecs.

Deloitte (2012), EMEA Tax Certainty Survey: Survey on the Relationship with Tax Authorities throughout EMEA, available at http://public.deloitte.com /media/0564/index.html, accessed at 20.10.2013.

Dinga, E. (2009), Studii de economie. Contribuţii de analiză logică, epistemologică şi metodologică, Bucureşti, Editura Economică.

Florescu, D., Coman, P., Bălaşa, G. (2005), Fiscalitatea în România: doctrină, 
reglementare, jurisprudenţă, Bucureşti, Editura All Beck.

Franzoni, L. (2000), Tax Evasion and Tax Compliance, in Encyclopedia of Law and Economics, eds. Bouckaert, B. and De Geest, G., vol. IV, Cheltenham: Edward Elgar.

Hoanţă, N. (1997), Evaziunea fiscală, București, Editura Tribuna Economică.

Inceu, A. M., Lazăr, D. T., Mara, E. R. (2008), Finanţe şi bugete publice, ClujNapoca, Editura Accent.

James, S., Alley, C. (2002), Tax Compliance, Self-assessment and Tax Administration, Journal of Finance and Management in Public Services, 2(2), pp. 27-42.

Kirchler, E., Hoelzl, E., Wahl, I. (2008), Enforced versus Voluntary Tax Compliance: The "Slippery Slope” Framework, Journal of Economic Psychology, 29 (2), pp. 210-225.

Moraru, D., Nedelescu, M., Stănescu, C. Preda, O. (2007), Finanţe publice: sinteze, aplicaţii, teste-grilă, Bucureşti, Editura Economică.

Muehlbacher, S., Kirchler, E., Schwarzenberger, H. (2011), Voluntary versus Enforced Compliance: Empirical Evidence for the "Slippery Slope" Framework, European Journal of Law and Economics, 32, pp. 89-97.

Richardson, G. (2008), The Relationship between Culture and Tax Evasion Across Countries: Aditional Evidence and Extensions, Journal of International Accounting, Auditing and Taxation, 17, pp. 67-78.

Smith, A. (1965), Avuţia naţională, vol. II, Bucureşti, Editura Academiei Republicii Populare Române.

Şaguna, D. D. (2003), Drept financiar şi fiscal, Bucureşti, Editura All Beck.

Tudose, M. B. (2008), Finanţe. Elemente teoretice şi practice, Iaşi, Editura Sedcom Libris.

Tulai, C. (2003), Finanţele publice şi fiscalitatea, Cluj-Napoca, Editura Casa Cărţii de Ştiinţă.

Țâtu, L., Şerbănescu, C., Ştefan, D., Vasilescu, D., Nica, A. (2004), Fiscalitatea de la lege la practică, Bucureşti, Editura All Beck.

Văcărel, I. coord. (2006), Finanţe publice, ed. a VI-a, Bucureşti, Editura Economică.

Wahl, I., Kastlunger, B., Kirchler, E. (2010), Trust in Authorities and Power to Enforce Tax Compliance: An Empirical Analysis of the "Slippery Slope Framework”, Law \& Policy, 32(4), pp. 383-406.

Zaharia, V. (2002), Finanţe publice, Cluj-Napoca, Editura George Bariţiu. 